found decorative rather than useful. One is put in mind of the costly and over-elaborate hi-fi consoles and cameras of today, which seem to reveal more of the aspirations of the owner than anything else.

So it is fitting that we should rehabilitate the reputation of the simple microscope. Through its diminutive lens were discovered the nucleus, bacteria, and a host of cellular structures that had widespread effects on the progress of medicine and biology. We owe it respect; and it might prove to be a useful ally for student use in the increasingly cost-effective era into which we are moving.

The help of the Royal Society, the University of Utrecht, the Linnean Society, and the Department of Zoology, University College, Cardiff, is gratefully acknowledged. This work has been supported by grants from the Linnean Society, the Kodak Bursary Scheme, and the Royal Society of London.

\section{References}

${ }^{1}$ King LS, ed. A history of medicine. London: Penguin, 1971:3.

2 Zuylen J van. The microscopes of Antony van Leeuwenhoek. Fournal of Microscopy $1981 ; \mathbf{1 2 1}: 682-5$.

${ }^{3}$ Ford BJ. The Leeuwenhoek specimens. Notes and Records of the Royal Society $1981 ; 36: 37-59$.

4 Bradbury S. Evolution of the microscope. Oxford: Pergamon, 1967:73.

5 Ford BJ. Leeuwenhoek's specimens discovered after 307 years. Nature $1981 ; 292: 407$

"Dobell C. Antony van Leeuwenhoek and his "little animals." London: John Bale, Sons and Danielsson, 1932.

${ }^{7}$ Hooke R. Micrographia, or some physiological descriptions of minute bodies made by magnifying glasses; with observations and inquiries thereupon. London: Martyn and Allestry, Royal Society, 1665. (Reprinted by Dover Publications Inc, New York, 1961.)

${ }^{*}$ Hooke R. Micrographia, or some physiological descriptions of minute bodies made by magnifying glasses; with observations and inquiries thereupon. London: Martyn and Allestry, Royal Society, 1665: preface xxii. ${ }^{9}$ Ford BJ. The cell nucleus 150 years on. Biologist $1982 ; 29: 47$.

${ }^{10}$ Carpenter WB. The microscope and its revelations. 3rd ed. London: Churchill, 1862.

\title{
A health hazard
}

\author{
RICHARD BAYLISS
}

Mr John Pringle, MS, FRCS, parked his car with dexterity-it had power-steering - and ignored the parking meter. At $530 \mathrm{pm}$ it was worth the risk; the wardens would be on their way home, he hoped. He was as eminent a surgeon as one could be in a noneminent society. He approved of this. The stage had undergone the same metamorphosis as medicine. Now there were fewer stars in the theatre and more generally good flexible actors and actresses. Gone were the days of the Lords Lister and Moynihan, just as there were now fewer Cowards, Lunts, and Thorndykes. In general, he reflected, the change had been for the good. The overall standard across the country had been raised and there were fewer pontificating gods. The growth of medical knowledge had made omniscience impossible.

As he stepped on to the pavement $\mathrm{Mr}$ Pringle discreetly dropped his cigarette end down the grated drain-cover in the road. Quite unconsciously he coughed as he climbed the six shallow steps to the main doors of the hospital.

Emerging from the lift on the fourth floor, the chequered garish carpet lining the hall and extended corridor made him feel slightly dizzy. Its tastelessness did not impinge further as he greeted Dr Fowler, occupied at the nurses' station. Mr Pringle liked Dr Fowler, though he did not know him well. A general practitioner, aged about 40, with an FRCS and an MRCGP, who had been a senior surgical registrar, was a comparative rarity.

"Mrs Nolan," Fowler explained about the patient they were about to see, "is aged 45 . She asked me to see her for the first time yesterday. She comes from Dallas and is a Christian Scientist." He paused to let the significance of this last remark sink in. "She developed thyrotoxicosis two years ago. After six months, when she was very ill and had lost a lot of weight, her husband, who is not a Christian Scientist, persuaded her to see a doctor. She started taking an antithyroid drug and within three months was immeasurably better. Now ..."”

\section{London NW1 4LJ}

SIR RICHARD BAYLISS, MD, FRCP, endocrinologist
"Don't tell me," said Pringle, "let me find out the rest for myself."

Mrs Nolan was propped up in bed. She was jaundiced and emaciated. Her animation and her prominent eyes contrasted with her thinness and extreme dyspnoea that made talking difficult. Even in illness she was elegant and attractive. From the side of the bed Pringle could not fail to notice the prominence of her neck veins. The pulsation in her jugulars extended to her ear lobes which pulsated regularly with each right ventricular contraction. "Surprising," he thought, "that she is still in sinus rhythm and has not developed atrial fibrillation."

"Yes," Mrs Nolan said in answer to his question, "I improved greatly with the doctor's treatment, but I am a Christian Scientist so I came to England to receive Christian Science treatment."

"My wife promised to continue taking the tablets our doctor in Dallas prescribed," interjected her husband, grey with concern, "but she threw them away, down the lavatory, as her plane took off for Heathrow."

"And ... ? ?," prised Mr Pringle gently.

"And," said Mrs Nolan, "I have been in this Christian Science Hospital in England for three months but I am no better."

There was no disputing this. She was oedematous, grossly so, from her toes up to her mid-thorax. The pulse, initially 130 , had dropped, said Dr Fowler, with digoxin and a small dose of propranolol to 80 . She was taking $80 \mathrm{mg}$ frusemide and had just restarted antithyroid treatment-10 mg carbimazole four-hourly. Mr Pringle noted the severity of the heart failure, the gross oedema, the ascites, the enlargement of the heart, and the bilateral pleural effusions shown on the chest $x$-ray film. He sighed.

During the ensuing discussion he was gentle-and optimistic. Alone outside the room with the husband, he said "The next week is likely to be critical. Your wife's jaundice is an index of the severity, of the gravity, of the heart failure which is secondary to her thyrotoxicosis. If she gets better over the next few days it is probable that with proper medical treatment she will make a complete recovery." He emphasised the word "proper" and then, after a pause, added "There is no place for Christian Science in this situation, I am afraid, but this you know." "It is a health hazard" replied Mr Nolan. "Indeed," reiterated Pringle quietly, "a health hazard." 
As he drove home Mr Pringle reflected on the frailty of human beings, their vulnerability, their weaknesses, their illogicalities. All this could so easily have been avoided. Heart failure from untreated hyperthyroidism was a disease of the past. It never happened now except ... except when patients did not understand or want to understand.

\section{* $\quad * \quad$ *}

He woke and groped for the telephone. "Can you comequickly," asked Dr Fowler, "I am sorry for calling you. . . ."
Pringle clambered out of bed, half-asleep. It was $3 \mathrm{am}$. She was dead when he arrived at the hospital. "Some dysrhythmia or just pulmonary oedema?" he wondered as he stared at Mrs Nolan lying in the bed, her auburn hair neatly combed, her eyes closed, her attractive face turned to the ceiling, her slender sunburnt arms and hands with well cared for nails still outside the counterpane.

As he walked slowly and sadly down the six steps of the hospital into the stillness of the cold night air he coughed unconsciously. "What a health hazard," he mused, "Should never have happened." He lit a cigarette as he drove away.

\title{
Florence
}

\author{
E SAPHIER
}

I fell abrooding when I saw the holiday ad. A picture came up in my mind's eye. Sharp, clear, precise, and complete with its little package of emotional content. There was my cousin Florrie 70 years ago, and my brother crawling under the table about to take a bite out of an apple she was dangling. The same picture, the same detail every time. How on earth does the mind's eye work?

Up came the next slide showing my classroom. The lesson was about Florence Nightingale and my pal called her "The lady with the lump." He had to write "lamp" 100 times.

Then followed a clear view of our entering the City of Florence one Sunday morning. I do not think Florence is all it is cracked up to be. One lot of art is very much like another. It was really very hot. I am afraid we headed straight out again. Mind you, we had spent some time previously admiring a masterpiece with the aid of a cassette recording. We made all the right noises, and it was a shock to learn that we had been listening to the wrong tape.

\section{Dr A Leslie Florence}

My computer then continued its program with the shot that really mattered. It was the front cover of the $B M F$ : the date 31 December 1960. There, in letters of fire on an out-of-the-blue background under the heading Correspondence was the title of a letter from a general practitioner named Florence. Dr A Leslie Florence to be precise. Well, not letters of fire actually. More like black.

When I was a kid, I read Harry Wharton, Bob Cherry, Sexton Blake, and H S Partington with equal gusto. Partington had written a smashing book called Intermediate Chemistry. I did not understand it all, but I used to savour the lovely terms which seemed to capture essential truth, and fit everything precisely in its place in the scheme.

When I qualified I still doodled with structural formulas, and I preferred the chemical to the trade name of drugs. I must have been one of the few general practitioners around who knew the proper name for Distaval. That was why I read the $B M \mathcal{F}$ that New Year's Day instead of throwing it away. The letter was entitled "Is thalidomide to blame?" and I was intrigued. (It

Health Centre, Sutton, Surrey SM1 2RJ

E SAPHIER, MRCS, LRCP, general practitioner was not until 2 December 1961 that the first warnings of the teratogenic effects of thalidomide were given in the Lancet.)

Unlike the city, I do not know that Dr Florence was ever cracked up to be anything special. I seem to remember his practice was in Scotland. When I came to look him up, years later, I could not find him in the directory. In all the name calling that ensued I do not remember his name being mentioned, and so far as I am aware, no tribute was ever paid him. Yet he must have saved a lot of suffering. The 21st anniversary of his letter is coming up. Perhaps it is not too late to pay him a tribute now.

The letter stated that he had given thalidomide to several elderly people who later developed a peripheral neuropathy. $\mathrm{He}$ could not think of any other likely cause and wondered if thalidomide was to blame. I too had had a similar patient. The letter clicked. I felt sure he was right. I never used thalidomide again. I told other people. They in turn told others. I remember a psychiatrist friend telling me how several of them had stopped using the drug. I also remember the picture of the little girl reaching up to the drug cupboard, advertising the safety of Distaval, which stayed in my surgery for years!

Nobody, of course, can ever possibly know who, if anyone, was saved. Yet there must be gentlemen in Surrey now afoot, and now aged 21, who would not have been afoot on St Crispin's or any other day if Dr Florence had not written his letter. Odd to think that the $B M F$ no longer prints the correspondence contents on the front cover. If the same thing had happened today I, for one, would never have known.

\section{The thought is not enough}

One last aspect, illustrated by what happened to my wife, after she had been driving in thick traffic for some time. She was stopped in a jam, when there was a tap on her window. A hand held out a piece of paper, a smile, a wave, a raise of the hat, and he was gone. On the paper she read "I take back all I've said about women drivers." Of course, I admire my wife, and her driving, but equally I admire the writer of this note. It was not enough to have the thought. He had to find some paper, a pen, actually write the note, get out of his car, deliver it, and get back before the traffic started. I have thoughts. Sometimes I get them down. Usually before I've got the paper, the message, the envelope, and especially the stamp together, the mood has passed. Dr Florence got it all together and delivered his message. I would like to say thanks. 